\title{
MAQÂSHIDÎ INTERPRETATION; A STUDY ON INTERPRETATION OF AHKAM VERSES IN THE APPLICATION OF MAQÂSHID ASY-SYARÎAH
}

\section{Candra Boy Seroza}

The Directorate General of Religious Courts, Supreme Court of the Republic of Indonesia

Gambir, Gambir, Jakarta, 10110

E-mail: candraboyseroza@gmail.com

Ahmad Hasan Ridwan

State Islamic University of Sunan Gunung Djati Bandung

Cipadung, Cibiru, Bandung, West Java, 40614

Email:ahmadhasanridwan@uinsgd.ac.id

\begin{tabular}{c|c|c}
\hline Received: & Revised: & Approved: \\
$31 / 01 / 2020$ & $13 / 06 / 2020$ & $30 / 06 / 2020$ \\
\hline
\end{tabular}

DOI: https:// doi.org/10.32332/akademika.v25i1.1898

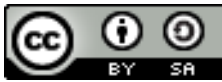

Maqâshidî Interpretation; A Study On Interpretation Of Ahkam Verses In The Application Of Maqâshid Asy-Syarîah Commons Attribution-

ShareAlike 4.0 International License

\begin{abstract}
This study explains Maqâshidî Interpretation and its application in interpretation Of Ahkam Verses, and aims to discussion on Maqâshid asySyarî'ah and the significance and urgency of Maqâshidî. Maqâshidî's inter-pretation is expected to provide an alternative interpretation in providing solutions for contemporary problematics and reinterpretation of the interpretation formulations that have been out of date. The research method used in this research is qualitative method and analytical descriptive method. This study concludes that The character of Syarî'ah is permanent and governs the whole af'âl al-Mukallaf in every place and time, then the approach or method of maqâshidî interpretation in interpreting Âyât al-ahkâm is a necessity and very imfortant. The discourse of Âyât alAhKâm interpretation discusses on the place of law formulation against a
\end{abstract}


problem (Fi'l al-Mukallaf). he necessity of interpretation of the approach or method of Maqâshidî interpretation is not only effective in responding to new issues that have never appeared before but also empowered to reinterpret the formulation of interpretations that have not been relevant anymore in the context of the present and the contemporary.

Keywords: Maqâshidî Interpretation, Maqâshid asy-Syarîah, Âyât alAhKâm,

\section{A. Introduction}

The Qur'an is Verbum Dei (The Words of Allah) delivered to the Prophet Muhammad SAW which is a miracle, serving by reading, demonstrated to us by Mutawâtir, begun with Surah Al-Fatihah and ended by Surah Al-Nas. ${ }^{1}$, However, due to Islamic is the last religion until the end of time, the instructions contained in the Qur'an are mostly in the global form, not technical instructions; therefore, the pronunciation or the words used in the Qur'an can accommodate changes of sociocultural that are always dynamic. ${ }^{2}$

The Prophet Muhammad SAW, who functioned as Mubayyin as well as the authoritative interpreter of the Noble Qur'an, also does not interpret all the verses of the Qur'an since there are no problems or urgency to describe at the time. Some of them are not uncommon to be out of date. This is reasonable as the interpretation is common as a response or an answer to the actual issue that occurred at the time as well as relevant to the current context.

To manifest the provisions, values, and norms implied in the Qur'an properly, relevant to the specific space and time, it is required the interpretation studies as the designation of Allah intentions is discussed within the Qur'an apparently to the human's ability. Due to the content of

${ }^{1}$ Mufiq Al-Din Abi Muhammad ' Abd Allah ibn Ahmad ibn Qudaamah AlMuqdisiy (hereinafter referred to as Ibn Qudamah), Rawdhat AlNâzhir Wa Jannat al-Manâzhir, Riyadh Maktabat al-Ma'ârif, t.th.), Juz 1,178. See Also: Manna ' Bin Khalil al-Qaththan, Mabâhits fí ' Ulûm al-Qur'ân, (Maktabah al-Mu'arif Li al-Nasyr wa al-Tawzi ', 2000), 3rd Print, 5.

${ }^{2}$ Line With Rules:

$$
\text { تغير الفتوى وإختلافها بحسب تغير الأمكنة والأحو ال و النيات و العو ائد. }
$$

See also: Ibn Qayyim AlJawziyyah, I'lâm al-Muwaqqi'în 'an Rabb al-'Âlamîn, (Beirut: Dar al-Jalil, 1975), Volume II, 95. See also: Muhammad 'Amim Al-Ihsan alMujaddiy al-Barkatiy, Qawâ'id AlFiqh, (AlKaratisyiyAlShadf Bibilsyuz, 1986), 113 
the Qur'an contains instructions for various issues of daily life, the interpretation is done in various perspectives as well. ${ }^{3}$

In literature, the interpretation studies consist of various interpretation types. There is a category of falsafiy interpretation, which disqualifies philosophical theories of wisdom, such as al-Farabi interpretation, Ikhwân al-Shafâ interpretation, and ibn Sinâ, interpretation ${ }^{4}$ in the category of shîfiy /Isyâriy interpretation, which emphasizes the contemplative ascent of the Sufi in differing the noble texts, such as $i b n$ ' Arabiy interpretation ${ }^{5}$, in the category of al-' scholarly interpretation ${ }^{6}$, which prioritizes the scientific knowledge found in the Qur'an, and there are the categories of al-Fiqhiy interpretation, such as al-Jashshâsh and al-Qurthubiy interpretations. ${ }^{7}$

The form of al-Fiqhiy interpretation is often referred to as the Âyât alahkâm interpretation. The interpretation of this category has usually discussed the verses of the law, by submitting the discourse and the opinion of the Fiqh scholars and the prioritized evidence. However, in the literature of al-Fiqhiy interpretation, as the development of jurisprudence in general, it specifically describes the opinion of the Fiqh scholars and often does not convey the review of the perspective of Maqâshid asy-Syarî'ah, which is the objebctive of the Islamic law. There appears an interpretation method, Maqâshid, that drives interpreter on the interpretation of the Qur'an verses for the application of the Maqâshid asy-Syarî'ah.

The question that arises is what approach or interpretation method which can lead an interpreter to interpret the verses of the law in the Qur'an in accordance with Maqâshid asy-Syarî'ah? Who is the person who has done such an approach? How is the example of the interpretation of the legal verses in the Qur'an relevant to Maqâshid asy-Syarî'ah? How is the significance of the interpretation of the verse of the law in the Qur'an correspond to the Maqâshid asy-Syarî'ahi t? Those are some focus of the study in this paper.

\section{B. Discussion}

There are some studies on the method of the Qur'an interpretation in Interpretation Literature Studies. From classical interpretation methods,

${ }^{3}$ Muhammad ' Abd al-'azhim al-Zarqaniy, Manâhil al-'irfân fì ' Ulûm alQur'ân, (TKP: Mathba'ah ' Isa al-Babiy al-Halabiy, t.th.), 3 $3^{\text {rd }}$ Print, Juz 2, 3.

${ }^{4}$ Muhammad Al-Sayheed Husayn Ad-Dhahabî, Al-Tafsîr al-Mufassirûn, (Cairo: Maktabah Wahbah, 1398 H), Juz ' 2, 309-310.

5 Ad-Dhahabî, 250-251.

6 Ad-Dhahabî, 319.

7 Ad-Dhahabî, 319. 
such as Bi al-ma'tsûr interpretation ${ }^{8}$ and A Bi al-Ra'y interpretation ${ }^{9}$ to the interpretation of the hermeneutics is replaced by several circles in Islam, always viral to discuss and debate. As well as the interpretation of Qur'anic approaches, from falsafiy interpretation, shûfiy/Isyâriy interpretation, al'ilmiy interpretation, to al-Fighiy interpretation.

In line with the development of science today and the variety of problems that must be faced by mankind, they carry a considerable impact on the development of interpretation approaches, especially in interpreting the legal verses that are related to af âl al-Mukallaf.

Theoretically, this is reasonable due to several things: first, the end of the revelation after the death of the Prophet Muhammad SAW; Second, the Qur'an as scripture is deliberately created responsive to the dynamic circumstances so that it is always relevant to every space and time (up to date/Shâlih Li Kull zamân wa al-Makân) until the end of the day; therefore, the pronunciation used in the Qur'an is generally 'Âm, Muthlaq, and other interpretable categories. When analogized to the condition in Indonesia, the Qur'an is Pancasila, repeatedly amended by legislation, even the Constitution 1945, the meaning is still maintained by Pancasila. Therefore, the development of Âyât al-ahkâm interpretation is a necessity.

Conducting a review on Islamic law ${ }^{10}$ is inseparable from the study of the Maqâshid asy-Syarî'ah, as it is the main purpose of the determination of the Islamic law. In the scientific methodology of Islamic law, the perspective of Maqâshid asy-Syarî'ah is an inevitability.

\section{The Definition of Maqâshid asy-Syarî'ah}

The term "Maqâshid asy-Syarî'ah" is murakkab idhâfí, consisting of two words, "Maqâshid" and "asy-Syarî'ah". The word "al-Maqâshid" etymologically is a plural form of the word "Maqshad", where the word "Maqshad" itself is a Mashdar Mîmiy, derived from the word "Qashada"

${ }^{8}$ Ad-Dhahabî, 112.

${ }^{9}$ Ad-Dhahabî, 183.

10See also: ' Abd al-Wahhab al-Al-'allamah al-Bannaniy, Hâsyiyah al-Bannaniy ' Alâ Sharh al-Mahalliy ' Alâ Matn ' al-Jawâmi ', (Beirut: Dar al-Fikr, 1992) Vol. I, 25. See also: Muhammad ibn Mukram ibn Manzhur, Lisân al-' Arab, (Beirut: Dar Shadir, t.th.), Juz ' 2, 313. Al-Mâ'idah: 48, Asu-Syûrâ: 13, and AlJâtsiyah: 18. See also: Subhi Mahmasani, Falsafat At-Tasyrî Al-Islâmi, Translator: Ahmad Sujono, Filsafat Hukum dalam Islam (Bandung: Al-By ali $\mathrm{m}$, 1982), 10. See also: Amir Syarifuddin, Ushul Figh (Jakarta: Logos Wacana Ilmu, 1997), 1st Print., 5. 
which means the same as the word "Qashdan"11. According to Arabic linguists, the word "Maqshad" etymologically has some meanings: ${ }^{12}$ first, Al-I'timâd, al-Umm, Ityân al-Shai', and al-Tawajjuh, secondly, Istiqâmat alTharîq, third, al-'adl, al-Tawassuth, and 'Adam al-Ifrâth, and fourth, al-Kasr min fi ayy wajh kân. Based on the etymology of the word "Maqshad" above, the first meaning is a relevant meaning to understanding Ishthilâhiy with the object of this study since there are Al-umm, al-I'timâd, Ityân al-Shai', and al-Tawajjuh which entirely discuss the desire and determination of accomplishment (tadûr hawl irâdat al-Shai 'wa al-'azm 'Alaih). The words asySyarî'ah" etymologically means al-Dîn, Al-Millah, Al-Minhâj, al-Tharîgah, and al-Sunnah ${ }^{13}$. According to its root word, it is used to mention Mûrad alSyâribah (where the Giver comes) ${ }^{14}$. In the terminology, according to Ibn Taymiyah, it means: thâ'at Allâh wa rasûlih wa ulîal-amr minnâ ${ }^{15}$ (obeying Allah, the Apostles and the leaders among us).

The definition of Maqâshid asy-Syarîah has not been found in the previous books of Ushîl al-Figh until the scholars have an intention to the issue of Maqâshid asy-Syarî'ah, such as Al-Ghazaliy ${ }^{16}$ and Al-Shathibiy ${ }^{17}$. At that phase, they only present a part of the concept or division of Maqâshid asy-Syarî'ah. Al-Ghazali, for example, does not present a definition of Maqâshid asy-Syarî'ah, He only conveys restrictions of Maqâshid asy-Syarî'ah. Al-Ghazali conveys as follows:

${ }^{11}$ Abi Al-Husayn Ahmad bin Faris bin Zakariya (d. 395 H), Mu'jam Maqâyis al-Lughah, cited by 'Abd al-Salam Harun, (Egypt: Mushthafa al-Babiy al-Halabiy, 1392 H), $2^{\text {nd }}$ Print, Juz ' 5, 95.

${ }^{12} \mathrm{Abi}$ ' Abd al-Rahman al-Khalil bin Ahmad al-Farahidiy (d. $\left.175 \mathrm{H}\right), A l$-'ain, cited by Muhdiy al-Makhzumiy, (TKP: Mu'assasah al-A'lamiy, t.th.), Juz ' 5, 54.

${ }^{13} \mathrm{Abi}$ Al-Husayn Ahmad bin Faris bin Zakariya (d. $395 \mathrm{H}$ ), "Majmal alLughah cited by Zuhair ' Abd al-Muhsin Sulthan, (Beirut: Mu'assasah al-Treatise, $1406 \mathrm{H}), 2^{\text {nd }}$ print, Juz ' 2, 526. See also: Isma'il ibn Hammad al-Jawhariy (d. $\left.393 \mathrm{H}\right)$, Al-ShaHhâh, cited by Ahmad ' Abd al-Ghafur ' Athar, (TKP: TPN, $1402 \mathrm{H}), 2^{\text {nd }}$ print, Juz ' 3, 1236.

${ }^{14}$ Abi Al-Husayn, 1236.

${ }^{15}$ Ibn Taymiyah, ' Majmu Al-Fatâwâ ', Compiled by 'Abd al-Rahman bin Qasim al-Najdiy and his son, Muhammad, (Mecca: Maktabah al-Nahdhah alHaditsah, T.Th.), Juz ' 19, 309.

${ }^{16}$ Taj al-Din ' Abd al-Wahhab ibn ' Aliy ibn ' Abdal-Kafiy al-Subkiy (hereinafter called Ibn Subkiy) (d. $771 \mathrm{H})$, Al-Sha'qât al-Shâtìyah (Beirut: Dar alMa'rifah, T. Th.), 2nd Print., Juz ' 4, 101.

171 Abdullah Mushthafa al-Maraghiy, Al-Fath al-Mubîn fì Thabaqât alUshûliyyîn, (Beirut: Dar al-Kutub al-'ilmiyyah, 1394 H), 2nd Print., Juz ' 2, 204. 


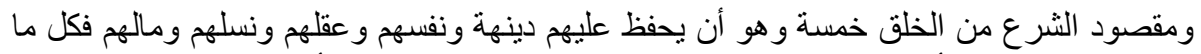

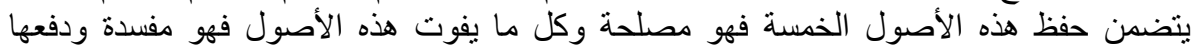

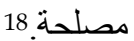

"There are 5 purposes of the law determination for mankind, namely to nurture their religion, soul, mind, posterity, and possessions. Each containing the preservation content of the five points above is a benefit, while each containing an abandonment content from the five points is modesty in which the benefit rejects it".

Similarly, asy-Syathibî, although he devotes his utmost attention and has a plenary understanding in the field of Maqâshid asy-Syarî'ah, he does not express its definition. ${ }^{19}$

The definition of the new Maqâshid asy-Syarî'ah appears in the previous books, either in the books of Maqâshid asy-Syarî'ah or in the books of Ushîl al-Figh. One of them is conveyed by Ibn ' Assyrians:20

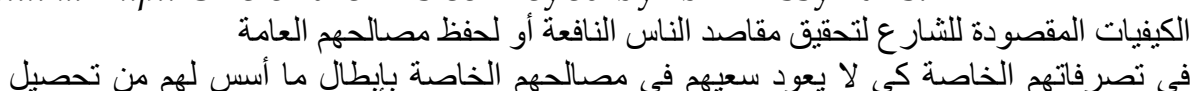

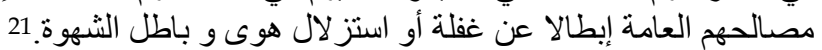

"The means of the Syâri ' to realize the objectives that are beneficial to man or to preserve their poverty in general in the Tasharuf that they are doing specifically to the efforts of their benefit specifically do not return by denying their generalized acquisition in general that was built for them due to negligence, failed by their lust.

Allal al-Fasiy defines ${ }^{22}$ Maqâshid asy-Syarî'ah by:

$$
\text { الغاية منها والأسر ار التي وضعها الثار ع عند كل حكم من أحكامها.23 }
$$

${ }^{18} \mathrm{Abu}$ Hamid Muhammad ibn Muhammad ibn Muhammad al-Ghazaliy (hereinafter called Al-Ghazaliy) (d. $505 \mathrm{H}$ ), Al-Mustashfâ, cited by Muhammad Mushthafa Abi al-'ala, (Egyptian: Maktabah al-Jundiy, t.th.), 251.

${ }^{19}$ Ahmad al-Raisuniy, Nazhariyyat al-Maqâshid 'ind al-Sythibiy, (tkp: Mathba'ahal-Najah, $1411 \mathrm{H}), 1^{\text {st }}$ Print, 5. Muhammad Sa'd bin Ahmad bin Mas'ud Al-Yubî (hereinafter referred to as al-Yubî), Maqâshid al-Syarî'ah al-Islâmiyyah wa 'Alâqatuhâ bi al-Adillat al-Syar'iyyah, (Riyadh: Dar al-Hijrah li al-Nasyr wa al-Tawzî ', 1998 A.D), 34.

${ }^{20}$ Khair al-Din al-Zarkaliy, al-A'lam, (Beirut: Dar al-`Ilm li al-Malayin, 1992 CE), 10th Print, Juz 6, 174.

${ }^{21}$ Muhammad Ibn al-Thahir ibn ' Assyria (hereinafter called Ibn ' Assyria), "Maqâshid al-Syarî'ah al-Islâmiyyah, (Tunisia: Syirkah al-Tunisiyyah, 1978 A.D.), 1st Cet., 146.

${ }^{22}$ Khair al-Din al-Zarkasy, 246. 
"The purpose of the syari'ah and the secrets prescribed by Syâri ' on every law".

According to Al-Raisuniy, Maqâshid asy-Syarî'ah is:

الغايات التي وضعت الثريعة لأجل تحقبقها لمصلحة العباد.24

"The purposes determined by the syari'ah to realize the benefit for His servants".

The Wahbah al-Zuhailiy defines Maqâshid asy-Syarî'ah by:

"المعاني و الأهداف الملحوظة في جميع أحكامه أو معظمها أو هي الغاية من الثريعة و الأسرار التي

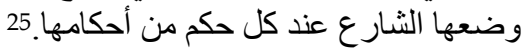

"The Meanings (' Illah-'illah) and the purposes observed in all or most of the law, or the purposes of Syâri and the secrets determined by the Syâri ' in every law".

It can be considered that the definition of Maqâshid asy-Syarî'ah that meets the elements jâmi' (covering the whole of the elements) and mâni ' (countering the non-elements) is the definition to be discovered by alYubiy: ${ }^{26}$

العباد. المي و الحكم ونحوها التي راعاها الثارع في التشريع عموماو خصوصا من أجل تحقيق مصالح

"'Illah-'allaah, wisdom, and others, that are kept by the Syâri ' in establishing the law, both common and special categories of purposes, to manifest the whole benefit for His servants".

The meaning of the word "Ma'ân is "' Ilal ('illah-'illah)", where the term is popular among the scholars. ${ }^{27}$ In the terminology of Ushûl al-Fiqh, the word "' Illah" is used in two meanings: a) meaning that is munâsib (accordingly) with the determination of the law; this meaning is referred to in the above definition, and b ) a clear and measurable nature with the determination of the law based on it will be obtained by the benefit.

${ }^{23}$ Muhammad 'Allal bin 'Abd al-Wahid bin 'Abd al-Salam al-Fasiy al-Fahiriy (hereafter called 'Allal al-Fasiy), "Maqâshid al-Shara'ah al-Islâmiyyah wa Makârimuhâ, (Moroccan: al-Risalah, 1979 A.D.), 2nd Print, 3.

${ }^{24} \mathrm{Ahmad}$ Ar-Raisuni, Nazhariyyat al-Maqâshid ' Ind al-Syâthib̂̂, 7.

${ }^{25}$ Wahbah Al-Zuhaili, Ushûl al-Figh al-Islâmiy, (Syria: Dar al-Fikr, 1406 H), 1st Print., Juz' 2, 1017.

${ }^{26} \mathrm{Al}-\mathrm{Yubî}, 37$.

27Muhammad Ibn Idris as-Shafi'i, Al-Risâlah, cited By: Ahmad Muhammad Syakir, (Beirut: Al-Maktabah al-'ilmiyyah, t.th.), 40, 512, 531, and 542. 
The meaning of the word "Hikam (plural form of the word ' $h i k m a h ') "$ in the above definition is the same as Nakna in the terminology of Ushîl alFigh, that is because of the existence of the wisdom, a trait can be used as As'illah. ${ }^{28}$

The meaning of the word "wa nahwuhâ" in the above definition is to cover other pronunciation that is viewed as part of Maqâshid, such as alHadf, Al-Ghâyah, al-Fâ'idah, and al-Tsamrah. It is not a form of doubt due to its existence as clear from Idhâfah to Dhamîr.

The meaning of the word "al-Latiy râ'âhâ al-Syâri ' fì al-Tasyrî̀'" in the above definition which is noted, deliberated and desirable Syâri ' in establishing law and it is a clue that the laws of God have ' Illah and benefit that have been intentional by Syâri ', not a coincidence.

The meaning of the word "'umûmâ wa khushûshâ" in the above definition is to cover the law and the purpose contained in the many propositions which are kept syâri ' in establishing the law, as well as cover wisdom or' Illah-'illah that are intended by Syâri 'on every law.

The meaning of the word "min ajl tahqîq mashâli $\underline{H}$ al-'ibâd" in the definition above is as a trait that explains clearly the purpose of the Maqâshid asy-Syarî'ah, that is only to manifest benefits for his servants in the world and in the hereafter. ${ }^{29}$

\section{The Division of Maqâshid al-Sharî'ah}

Reviewed from the level of benefit, Maqâshid asy-Syarî'ah has 3 levels, namely maqâshid Dharûriyyah (Primary aims), Maqâshid ĥÂjiyyah (Necessary aims), and maqâshid tahSîniyyah (improvements).30

According to al-Ghazaliy al-Dharûriyyât is: ${ }^{31}$

المصالح التي تتضمن حفظ مقصود من المقاصد الخمسة وهي حفظ الدين والنفس والعقل و المال

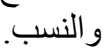

28Syihab Al-Din Abi al-'abbas Ahmad ibn Idris al-Qarafiy (d. $684 \mathrm{H})$, Sharh Tanqîh al-Fushûl, cited by Thaha ' Abd al-Ra'uf Sa'ad, (Egypt: Al-Muttahidah, 1393 H), 1st Print, 406.

${ }^{29} \mathrm{Al}-$ Yubî, 37-38.

${ }^{30} \mathrm{Ibrahim} \mathrm{Ibn} \mathrm{Musa} \mathrm{ibn} \mathrm{Muhammad} \mathrm{al-Lakhmî} \mathrm{al-Gharnathî} \mathrm{(known} \mathrm{as} \mathrm{asy-}$ Shathibî, hereinafter called: Asy-Shathibî), Al-Muwâfaqât, cited by: Abu' Ubaidah Masyhur ibn Hasan Al Salman, (TKP: Dâr ibn ' Affân, 1997 A.D/1417 H), Juz ' 3, 21.

${ }^{31}$ Al-Ghazaliy, Al-Mustashfâ, 251. See also: Abu' Abdillah Muhammad ibn ' Umar ibn Husayn al-Raziy (hereinafter called Al-Raziy) (d. $606 \mathrm{H})$, Al-Mahshûl fì' ' Ilm al-Ushûl, cited by Thaha Jabir, (Riyadh: Jami'ah al-Imam Muhammad ibn Sa'ud al-Islamiyyah, $1401 \mathrm{H}), 1^{\text {st }}$ Print, Juz ' 2, 220. 
"The benefits containing the maintenance of one of five maintenance purposes are the preservation of religion, soul, reason, treasure, and offspring".

According to al-Mahalliy al-Dharûriyyât is:32

"The needs in the level of al-Dharûrah".

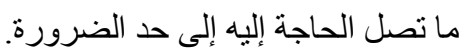

The substance of two definitions above is the same, namely maintaining the five Maqâshid asy-Syarî'ah which occupies the position of alDharûrah, where such poverty must exist, without it will result in an existence lost, perish, and falling into damage.

The definition of al- $\underline{\text { Hâjiyât }}$ is:

ما كان مفتقرا إليها من حيث التوسعة ورفع الضيق المؤدي إلى الحرج والمشقة اللاحقة بفوت

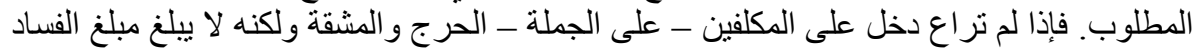
العادي المتوقع في المصالح العامة.

"Things that are needed, the form of space and the rapture of the distress that caused difficulties, in which if the thing does not exist, the difficulties will face. If the side of the Hâjiyyât is neglected, then a mukallaf-usually - will find difficulties, but will not cause damage due to the negligance of the common benefits".

The definition of al-tahsîniyyât is:

ما لا يرجع إلى ضرورة ولا إلى حاجة ولكن يقع موقع التحسين والتزيين و التيسير للمز ايا والمز ائد

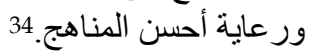

"The things that do not come to the aspects of Dharûriy and $\underline{H} \hat{A} j i y$, but are decorative ornamental; Beautify, streamline and make it easier to add privileges, advantages and nurture the best way".

32Jalal Al-Din Muhammad ibn Ahmad al-Mahalliy (d. $864 \mathrm{H})$, Syarh AlMahAlliy ' Alâ Jam ' al-Jawâmi ', (Beirut: Dar al-Kutub al-'ilmiyyah, t.th.), Juz ' 2, 28

${ }^{33}$ Asy-Shathibî, Al-Muwâfaqât, 11. Abual-Ma'aliy ' Abd al-Muluk ibn ' Abdillah al-Juwainiy (d. $478 \mathrm{H}$ ), Al-Burhân fî Ushûlal-Fiqh, cited by ' Abd al-'azhim Dib, (Cairo: Dar al-Anshar,1400 H), 2nd print, Juz'2, 924. Muhammad ibn al-Thahir ibn ' Assyrian, 82. Saif al-Din ' Aliy ibn Abi 'Aliy ibn Muhammad al-Amidiy (hereinafter called al-Amidiy), Al-Ihkâm fî Ushûl al-Ahkâm, (Beirut: Al-Maktab alIslâmiy, 1402 H), Juz ' 3, 274.

${ }^{34}$ Al-Amidi, 275. Al-Ghazaliy, 252. IBn Qudamah, 413. Jamal al-Din ' Abd alRahman ibn al-Hasan al-Isnawiy (d. 772 H), Nihâyat al-Sawl fî Syarh Minhâj alUshûl, (Beirut: 'Alam al-Kutub, t.th.), Juz ' 4, 86. 
Al-Raziy defines al-tahsîniyyât simply:

$$
\text { تقرير الناس على مكارم الأخلاق ومحاسن الثيم.35 }
$$

"A provision among mankind about the glory of ethics and the goodness of an action".

\section{E. The Postulates of Maqâshid al-Sarî'ah}

Among the postulates indicating the maintenance of al- Dharûriyyât al-Khamsah is in al-Anbiya ' verse 107:

$$
\text { وما أرسلناك إلا رحمة للعالمين. }
$$
all nature".

"We will not send thee (o Muhammad) except as a mercy for

According to Al-'adhd, the meaning of Zhâhir above verse is general, it means, based on the verse, it is understood that the commandment to keep the benefit of human beings in the laws prescribed to them. If Prophet Muhammad SAW is sent by carrying the laws that do not give the benefit so it means the condemnation is not carrying mercy, so that means the rules are not beneficial. This is contrary to the notion of Zhâhir above. ${ }^{36}$

In understanding the verse above and the few who are sidening it, asy-Syathibî argues that the verse includes a verse showing the syari'ah laying for the benefit of man. ${ }^{37}$

Likewise in Sura Al-An'am verse 151-153:

Say, "Come, I will recite what your Lord has prohibited to you. [He commands] that you do not associate anything with Him, and to parents, good treatment, and do not kill your children out of poverty; We will provide for you and them. And do not approach immoralities - what is apparent of them and what is concealed. And do not kill the soul which Allah has forbidden [to be killed] except by [legal] right. This has He instructed you that you may use reason. And do not approach the orphan's property except in a way that is best until he reaches maturity. And give full measure and weight in justice. We do not charge any soul except [with that within] its capacity. And when you testify, be just, even if [it concerns] a near relative. And the covenant of Allah fulfill. This has He instructed you that you may remember. And, [moreover], this is My path, which is straight, so follow it; and do not follow [other] ways, for you will be

${ }^{35}$ Al-Raziy (W. 606 H), 222.

${ }^{36}$ 'Adhd Ad-Din 'Abd al-Rahman bin Ahmad al-Ijiy (d. 756 H), (Beirut: Dar al-Kutub al-'ilmiyyah, t.th.), Juz ' 2, 238.

${ }^{37}$ Asy-Shathibî, 246. 
separated from His way. This has He instructed you that you may become righteous."

Some of the verses above contain commandments to preserve alDharûriyyat. The commandment to preserve religion is in the phrase God

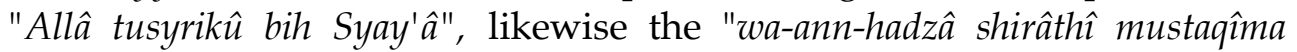
fattabi' ûh û wa lâ tattabi' $\hat{u}$ al-Subul fatafarraq Bikum ' an Sabîlih". In the phrase of the verse, it can be understood that Islam will not be enforced if accompanied by the attitude of God's condemnation. Because Allah commands that his servant call him in Ta'abbudiyyah, follow his straight path that there was no element of godhood in them from any side, and God forbade his servant to follow the devil's paths that lead to the valley of the fallacy.

The commandment to preserve soul is found in the phrase Allah's word "Walâ taqtulû awlâdakum min imlâq", as well as "Wa lâ taqtulû al-Nafs

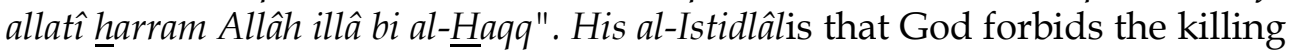
act except by law (Truth), and the murder by law aims to keep the soul, as referred to in the discourse on Qishâsh, to preserve religion, as referred to in the discourse on the Riddah, and to preserve offspring, as referred to in the discourse about Rajm.

The commandment to preserve the descendent is found in the word of God's phrase "WA lâ taqrabû al-fawâhisy m Zhahar minhâ wa m Bathan". For, among the biggest heinous deeds is adultery, which in other verses Allah has explicitly described adultery as an evil deed, as found in the letter of al-Isra ' verses 32.

The commandment to preserve treasure is found in the phrase of the Word of God "wa lâ taqrabû mâl al-yatîm illâ bi al-latî hiy ahsan hattâ yablugh Asyuddah", as well as "WA awfûal-kayl wa al-Mîzân bi al-qisth".

The commandment to preserve mind based on the verse, it can also be understood since the burden on the implementation of the entire Maqâshid above can only be realized by a well-known person. The phrase God's word at the end of the verse "La'allakum tattaqûn" indicates it.

So also the word of Allah SWT. In Sura al-Isra, paragraph 23-36 follows:

"And your Lord has decreed that you not worship except Him, and to parents, good treatment. Whether one or both of them reach old age [while] with you, say not to them [so much as], "uff," and do not repel them but speak to them a noble word. And lower to them the wing of humility out of mercy and say, "My Lord, have mercy upon them as they brought me up [when I was] small." Your Lord is most knowing of what is within yourselves. If you should be 
righteous [in intention] - then indeed $\mathrm{He}$ is ever, to the often returning [to Him], Forgiving. And give the relative his right, and [also] the poor and the traveler, and do not spend wastefully. Indeed, the wasteful are brothers of the devils, and ever has Satan been to his Lord ungrateful. And if you [must] turn away from the needy awaiting mercy from your Lord which you expect, then speak to them a gentle word. And do not make your hand [as] chained to your neck or extend it completely and [thereby] become blamed and insolvent. Indeed, your Lord extends provision for whom He wills and restricts [it]. Indeed $\mathrm{He}$ is ever, concerning His servants, Acquainted and Seeing. And do not kill your children for fear of poverty. We provide for them and for you. Indeed, their killing is ever a great sin. And do not approach unlawful sexual intercourse. Indeed, it is ever an immorality and is evil as a way. And do not kill the soul which Allah has forbidden, except by right. And whoever is killed unjustly - We have given his heir authority, but let him not exceed limits in [the matter of] taking life. Indeed, he has been supported [by the law]. And do not approach the property of an orphan, except in the way that is best, until he reaches maturity. And fulfill [every] commitment. Indeed, the commitment is ever [that about which one will be] questioned. And give full measure when you measure and weigh with an even balance. That is the best [way] and best in the result. And do not pursue that of which you have no knowledge. Indeed, the hearing, the sight, and the heart - about all those [one] will be questioned."

Some of the verses above also indicate to observe al-Dharûriyyât alKhamsah. The pieces of God's word "Waqadhâ Rabbuk allâ ta'budû illâ iyyâh" indicates to preserve religion, the piece of God's word "Wa lâ taqtulû al-Nafs allatîharram Allâh illâ bi al-hhAqq" indicates to preserve the soul, pieces of God's word "Wa âtî dzâa al-QurbâhAqqqah" to "innahûu kân bi ' ibâdih khabîrâ bashîrâ", also "Wa lâ taqrabûu mâl al-yatîm illâ bi al-latî hiy ahsan" to"ahSan Ta'wîlâ" indicates to keep the treasure.

The provision to maintain the descendant, nasab, and honor are also found in the pieces of the word of Allah "Wa lâ taqtulû al-Nafs allatî harram Allâh illâ bi al- $\underline{H} a q q "$ ", so also in "Wa lâ taqf Ma Lais Lakbih 'Ilm ".

To respond to the phenomenon of increasingly the development of science and various problematics that must be faced by human beings today, it seems that the interpretation through the approach or method of Maqâshidî (Maqâshidî interpretation) is a precise alternative approach, 
because the pattern of interpretation is considered to be able to answer the dynamic challenges of change, as well as the existence of the approach of Maqâshid asy-Syarî'ah in the field Al-Fiqh.

The term Maqâshidî interpretation for some circles currently is not familiar due to the study of Maqâshid asy-Syarî'ah that develops in Indonesia has not touched the study of Maqâshid in the interpretation method. In addition, in Indonesia, there are many scholars of Maqâshid asy-Syarî'ah. This differs from the study of maqashid asy-Syarî'ah in Morocco, Egypt, and other middle-eastern countries.

The word Maqâshidî in 'Maqâshidî interpretation' is the word Maqâshid which is composed by 'ya Nisbah. Thus, Maqâshidî interpretation is an interpretation using the approach of Maqâshid asy-Syarî'ah or in other words, Maqâshidî interpretation is an interpretation that explains the verses of the Qur'an by revealing and considering Maqûshid asy-Syarî'ah. These things differ Maqâshidî interpretation with other conventional interpretation, as described above.

Maqâshidî interpretation does not overlook the raw theories of interpretation, such as Asbâb al-Nuzĥul, 'Âm-Khâsh, Mujmal-Mubayyan, and others. In addition, Maqâshidî interpretation also notes the devices of general sciences, such as sociology, anthropology, and philosophy. ${ }^{38}$

Understanding Maqâshid asy-Syarî'ah for an interpreter is very urgency because Maqâshid asy-Syarî'ah is one of the tools of the interpretation that should not be ignored by the interpreter in the interpretation of the Qur'an. It is in accordance with what al-Fasiy said in his book Maq-shid Syarî' Ah wa Makâ rimuhâ, as quoted by Muhammad Sa'ad bin Ahmad al-Yubi, follows:

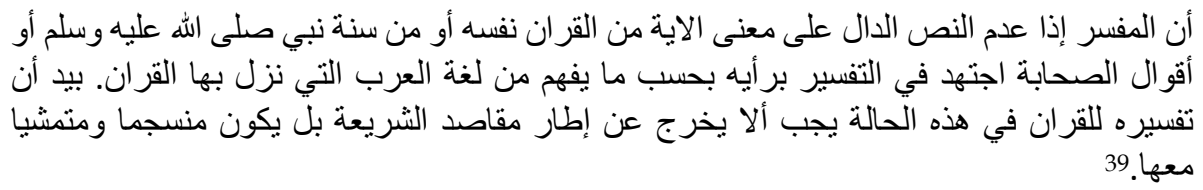

"If an interpreter does not find the Nash in the Qur'an, Sunnah, or aqwâl al-shahÂAah about the meaning of a verse, then he does Ijtihâd accordingly with the Arabic as he understands. Nevertheless, the interpretation of the Qur'an in this condition must not be out of the corridor Maqâshid asy-Syarî'ah, even it should be based on it".

${ }^{38 h t t p: / / m u h a m m a d i d r i s 84 . b l o g s p o t . c o m / 2009 / 11 / t a f s i r-m a q a s h i d i-~}$ sebuah-metode.html.

39 ‘Allal al-Fasî, 87-88. Al-Yubî, 487. 
With other editors, al-Syathibi expressed the importance of observing Maqâshid asy-Syarî́ah in understanding and interpreting the Qur'an, as follows:

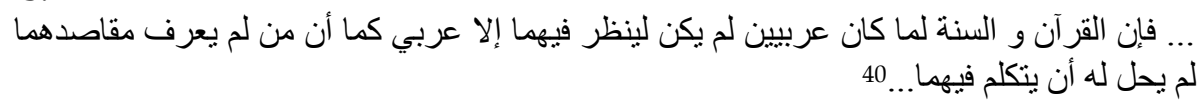

"... Qur'an and Sunnah in Arabic could only be understood by people (who understand Arabic), as well as people who do not know Maqâshid asy-Syarî'ah, should not talk to him about the Qur'an and The Sunnah. ..."

At the theoretical level, al-Qur'ân interpretation with the approach of Maqâshid asy-Syarî'ah do not completely reject the fresh idea offered by Western thought in its view of religious texts. Because this method of interpretation also accommodates the study of linguistics, sociology, anthropology, and history with a certain degree, and the Maghrib Arabi scholars who have the charge of Maqâshidî interpretation agree to put the verses of the Qur'an as a divine revelation (scripture) that cannot be bothered by its privileges and cannot be aligned with the human realm. This point distinguishes between hermeneutics ideas popularized by Western civilization (non-Moslem) with the idea of Maqâshidî interpretation that is carried by Islamic thinkers.

Meanwhile, Maqâshidî interpretation does not fully adopt the model interpretation that has been offered by classical scholars, especially those who limit the interpretation of Qur'an only bi al-ma'tsûr (with the history of hadith and the opinion of classical scholars). As such, this interpretation is more emphasized as an effort to find the proper method to interpret the verses of the Qur'an in accordance with modern human civilization. ${ }^{41}$

In interpreting the Qur'an, the attention to the aspect of Maqâshid asySyarî'ah is sometimes also shown in the classical interpretation. To mention the example, Muhammad Kajoui - an interpreter expert from the University of Muhammad V Maroko - suggests that in the book ahkâm alQur'ân by Ibn' Arabiy, there are many indications that lead to the conclusion that Ibn Al Arabi uses the approach of Maqâshid asy-Syarî'ah in interpreting the Qur'an. Among other things, the TarjI $\underline{h}$ in his book is always disguised on the side of the Maqâshid, such as interpreting Surah AlNur: 4 . He presents that the scholars agree when the allegations of adultery

40Asy-Shathibî, Juz ' 3, 31. See also: Al-Yubî, 488.

41http:/ / muhammadidris84.blogspot.com/2009/11/tafsir-maqashidisebuah-metode. html. 31 desember 2019. 
are expressed in a tashrih (explicit), so the law is al-Qadzf (defamation) should be in the whip law. However, if $t a^{\prime}$ rid (implicit). scholars differ in opinion, the Maliki madhhab sets the same as explicit, it means that it remains subject to the whip law, but according to Hanafi and Syafi's Madhhab, it does not include as al-Qadzf (defamation). In addressing this case, Ibn Al Arabi asserted that the Maliki madhhab is more appropriate because it approached the Maqâshid asy-Syarî'ah (Purpose) for the reason for the law of al-Qadzf.42

Similarly, the book of Tafsîr al-Tahrîr wa al-Tanwîr by Ibn Assyria, in this case, the contemporary writer al-Maisawi through his authorship strengthens; that Ibn's thought, in general, is widely influenced by the viewpoint Imam al-Shatibiy (d. $790 \mathrm{H})$. For this reason, it is not surprising that in interpretation the verses of the Qur'an, Ibn al-Assyrians refers to al-

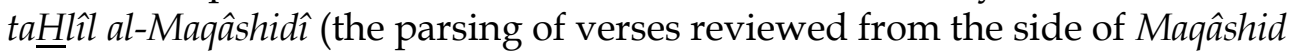
Asy-Syarî'ah) ${ }^{43}$

Ibn ' Assyria, when interpreting the letter of al-Nisa': 11, also expresses his opinion on Mawâni ' al-Irts, in which the person who killed misguided did not have any part of Diyyat.44 Such Interpretation formulations seem to also observe the aspects of Maqâshid asy-Syarî'ah. He hopes that with that formulation someone will take care to accelerate the procession of inheritance prematurely through the method of Sadd alDzarî' $a h .{ }^{45}$ This is also appropriate with the jurisprudence:

$$
\text { من استعجل شيئًا قبل أو انه عوقب بحرمانه.46 }
$$

42http:/ / muhammadidris84.blogspot.com/2009/11/tafsir-maqashidisebuah-metode. html. 31 desember 2019. See also: Abu Bakr Muhammad ibn ' Abdillah (popularly known as Ibn al-'arabiy) (d. 543 H), AhKâm al-Qur'ân, Cited by Muhammad ' Abd al-Qadir ' Atha, (Beirut: Dar al-Kutub al-'ilmiyyah, 2003 M), Juz ' 3,352 .

${ }^{43}$ http:/ / muhammadidris84.blogspot.com/2009/11/tafsir-maqashidisebuah-metode.html. 31 desember 2019.

${ }^{44} \mathrm{Ibn}{ }^{\prime}$ Assyrian (d. $1393 \mathrm{H}$ ), Al-Tahrîr wa al-Tanwîr (Tahrîr al-ma' nâ al-Sadîd wa Tanwîr al-'aql al-Jadîd min Tafsîr al-Kitâb al-Majîd), (Tunisia: Al-Dar alTunisiyyahlial-Nasyr, 1984 A.D), Juz ' 4, 259.

${ }^{45}$ Maqâshid al-syarî'ah has a very close relationship with the arguments of sharak. To explain this, Al-Yubî wrote a book titled Maqâshid al-Syarî'ah wa 'Alâqatuhâ bi al-Adillah al-Syar' iyyah.

${ }^{46} \mathrm{Abu}$ 'Abdillah Ahmad bin 'umar bin Musa'id al-Hazimiy, Sharh al-Qawâ'id wa al-Ushîl al-Jâmi'ah wa al-Furûq wa al-Taqâsîm al-Baa''ah al-Nâfi'ah http:/ / alhazme.net, Juz ' 8, 9. See also: Abu Muhammad ' Ali bin Ahmad bin Sa'id binHazm al-Andalusiy (d. $456 \mathrm{H}$ ), Al-IhKâm fî Ushîl al-AhKâm, cited by Ahmad Muhammad Syakir, (Beirut: Dar al-Afaq al-Jadidah, t.th.), Juz ' 6, 9. Ahmad ibn 
"Anyone who accelerates something prematurely is punished by not achieving it".

We can also look at the prespectives of the interpretation of Imam Khomaini through some of his writings, where the signal of the maqâshid approach on the view of the interpretation of Imam Khomaini is ever peeled by Abd. Salam Zainal Abidin, when dissecting his interpretation thinking through manhaj imâm khomaini fî al-Tafsîr (the method of interpretation of Imam Khomaini) says that Maqâshidî interpretation applied by Imam Khomaini refers to three important elements, namely; al-Riwôa' $\hat{\imath}$ (History), al-'irfân (Wisdom), and al-Tadabbur al-'aql (reason), these three essential elements then dominate the views of interpretation of the great leader of the Iranian revolution. ${ }^{47}$

Al-Shathibi presents an example of interpretation conducted without observing the aspect of Maqâshid asy-Syarî'ah. He describes the hypocrites who understand the Qur'an based on the wild sense that is far from the perspective of Maqâshid asy-Syarî'ah. For example, when understanding phrases the "Faqtulûu al-musyrikin haitsu wajattumûhum wa khudhûhum wahshurûhum waq'udî lahum kulla Marshad al-azaa'il wa ' al-shalâh wa ' âtû maaheen (Taâb ) in verse 5 of al-Tawbah, they understand that as long as they have embraced Islam, they must have freedom, where they do so to be safe from the world's torment. On that matter, Allah SWT (Maqâshid asySyarîhah) in this verse is in the form of ta'abbudiyah and khidmah to Allah SWT. 48

Prior to looking further at this significance of Maqâshidî interpretation, it is necessary to identify the characteristics of the Syarî'ah itself. It is since Maqâshidî interpretation, as described above, is closely correlated with Maqâshid asy-Syarî'ah.

\section{F. Characteristics of Syarî'ah}

The law of the Syari' ah is established to have a blessing and reject the failure of man in the world and in the Hereafter, as stated by Asy-Syathibî, saying, "The syari'ah is made only for the welfare of man, whether coming soon or slow". Therefore, it will not be found the welfare except the syâri '

Muhammad al-Zarqa ' (d. 1357, H), Syarh Al-Qawâ'id al-Fiqhiyyah, Tashhîh And Ta'liq by Mushthafa Ahmad al-Zarqa', (Syria: Dar al-Qalam, 1989 A.D.), 471.

47 Az-Zarqa', 471

${ }^{48}$ Al-Yubi, 488. 
has pointed out, and will not be found to be hypocritical unless syâri ' has forbidden or guarded it. ${ }^{4}$

Moreover, Syâri' motivates to obtain a beautiful harmonization between the world and the Hereafter and the individual and social welfare. Therefore, the scholars set the foundations, jurisprudence, and ushul, revealing the welfare and disregard it when there are opposition and contention. There is no doubt that the syari'ah keeps the whole time without being stopped on the law of one event.

Therefore, Allah SWT burden Himself in maintaining the provisions of the syari' ah, namely the primary Syari' ah source, the Quran, as His word in Sura al- $\underline{H}$ ijr verse 9:

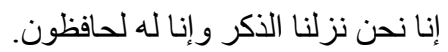

In addition, there is still the burden of Allah SWT towards Him to guarantee the permanent sharia, which is the consensus of the people who are not possible for error. A class always seeks to establish the truth where different groups of opinions will not harm them until the instruction of Allah Almighty, Allah Almighty send a reformer who can complete his religious affairs in every hundred years, and Allah SWT will send people who are able to bring syari'ah science and resubmit the erroneous change, cancellation, and conquests of syari' ah at all times..$^{50}$

In terms of the syari' ah of Allah SWT to perpetuate the sharia, Allah SWT guarantees it with some characteristics and privileges that make it relevant for each time and place. Among the most important characteristics, which can maintain syari'ah is the following two things:

1. The permanent Syari'ah law and the establishment of principle, namely revelation that comes from Allah SWT, either pronunciation or meaning only, although the revelation is disconnected from Prophet Muhammad SAW he is not erased. It is the correct and define a word, has eternal nature and no change and redemption, so on until the day of judgment. ${ }^{151}$

It is very important that there are a permanent law and rule that can be used as a patron in solving the legal issues of the category Juz'iyyât and furu' $\hat{u}^{\prime}$. The characteristic impermanent laws subject to permanent laws. If permanent laws subdue themselves to impermanent laws, there will be change and redemption, loss of patron of the raw and uncontinuity of the

${ }^{49}$ Asy-Syathibî, 9.

${ }^{50}$ Musfir Ibn Aliy Ibn Muhammad al-Qahthanî, Manhâj Istinbâth Ahkâm AnNawâzil Al-Fiqhiyyah Al-Muqah; Dirâsah Ta'shîliyyah Tathbîqiyyah, (Jeddah: Dar AlAndalus AlKhadhra', 2003 A.D/1424 H), Juz 1, 27-28.

51 Al-Qahthanî, 29-30. 
maintenance of value and the norm, no more ushîl (basic provisions) that are patrons return the problem, no longer the provisions of the benchmark, no more basic principles. This is what attracts people who claim to be modern, who want to change the religion of both the term and the problem of his branch with the soul, which they say, modernization, while they mean by modern it is in accordance with Western cultures, all of which are under renewed shields and reforms.

Thus, syari'ah does not require any addition. The patrons of syari'ah, Syariah include the achievement of the welfare and the rejection of its failure. Therefore, it is impossible if it is found a good one and can improve the human, world, and hereafter, but considered not in accordance with syari' ah provisions.

Therefore, it is determined that syari'ah law is permanent, unchangeable, in addition to that it is not permissible to do ijtihâd on it. Furthermore, the changing law that can do ijtihâd with the attention of Mashlahah, the law changes according to the change of society, conditions, times and places. Related to this matter, Ibn al-Qayyim says: "The law is two kinds: first, the law that does not change according to the changes of the times and places and not also the field of ijtihâd, as the face of all that is required and All that is forbidden, the $\underline{H} a d$ which is determined by Syara', etc., and secondly, the law that changes according to the Mashlahah demands by responsiveness to times, places and conditions, such as the size, type and nature of $T a^{\prime} z \hat{\imath}$. On this last assortment Syâri' has set its laws according to the aspect of welfare ".

Among the elasticity of syari'ah which is a special characteristic of Islamic Syari'ah is the response to the change of place and time. This does not imply the determination of the law and sharia rules, but the response to the changes only on the change of fatwa which belongs to the category of law accepting the above changes, as contained in the Fiqh rules expressed Ibn al-Qayyim:

$$
\text { تغيير الفنوى واختلافها بحسب تغير الأزمنة والأمكنة والأحو ال و النيات و العو ائد.52 }
$$

"The fatwa changes and differences according to the change of time, place, social conditions, intentions, and customs habits".

Later he comments:

52 Muhammad ibn Abi Bakr ibn Ayyub ibn Sa'd Syams Al-Din ibn Qayyim Aj-Jawziyyah, I'lâm al-Muwaqqi'în 'an Rabb al-'Âlamîn, cited By: Muhammad 'Abd al-Salam Ibrahim, (Beirut: Dar al-Kutub Al-'Ilmiyah, 1991 A.D/1411 H), Juz 3, 11. 


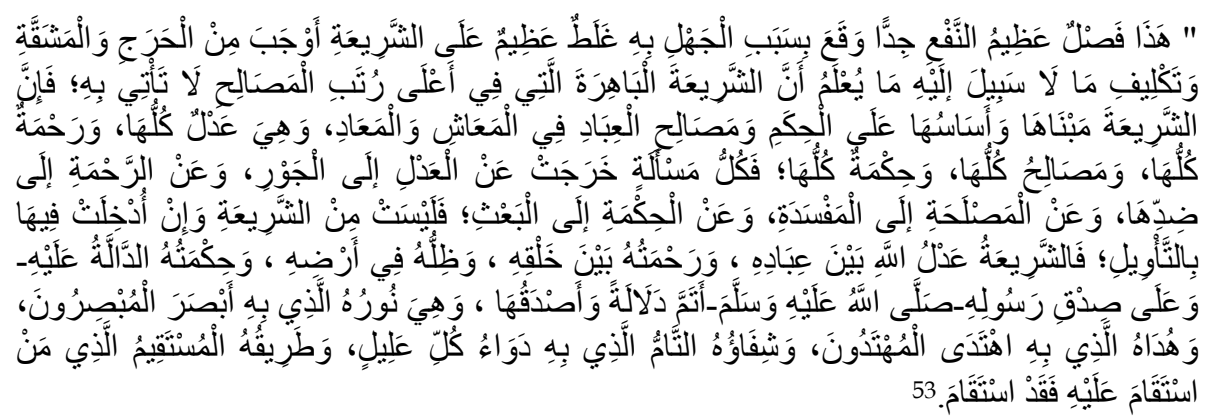

(This is a very rewarding point, not knowing it will be a major mistake on sharia; it will require that the difficulties and the judiciary, incriminating something there is no way. Indeed, sharia, which is the rule of the highest poverty, does not require it. Indeed, the foundation and principle of Sharia is the wisdom and existence of human beings in the world and the Hereafter, entirely fair, bring mercy, bring the blessing, and bring wisdom. Every problem that comes out of justice to the wrongdoing, from mercy to his opponent, from Mashla $\underline{H} a \underline{h}$ to Mafsadah, from wisdom to ba'ts, is not sharia, although it seems to be in accordance with the Islamic will using ta'wîl. Sharia is the application of the Justice of God to His servants, God's mercy toward His beings, the shade of God on His Earth, and the wisdom of God demonstrating His existence and the righteousness of His apostle is the appointment and truth Perfect, with the sharia light being shown to the one who can see, show the person who can be shown, the perfect remedy is the antidote to every disease, and his straight methods can make the category ' who asks to be Straight then he becomes straight '. "

Therefore, it can be concluded that the philosophy of making the law is permanent and partly arbitrary in accordance with the will of the blessing is to eliminate difficulties and be a mercy for the creatures.

Among the broad discussion of elasticity and change of law and fatwa is the determination of the law and fatwa conducted by the Fuqahâ ' by observing the changes ' Âdah, ' Urf, and ma ta'umm Al-Balwâ (customary customs). Who study comprehensively the books of Fiqh an-Nawâzil, such as al-Fatâwâ al-Hindiyyah, and Majmû' Fatâwâ by Ibn Taimiyyah, and others, it is obvious to him that the Fuqahâ ' is very concern about the customs change in establishing the law or the fatwa? Therefore al-Qarafiy considers it as the agreed rule that should be kept when it wasijtihâd or fatwa. The Ushîliyyûn create an istinbâth method known as the term' Urf shahlih.

${ }^{53}$ Aj-Jawziyyah, 11 
The change of law from one event to the other, is not as suspected by a group of people, that the change indicates the concern and unpermanencies of syari'ah law, but it means that syari'ah law is certain because of 'His gods, his sabab, and the one that he is, where when time, place, or condition changed, then changed the substance, 'he, and his sabab.

2. Syari'ah includes every condition in daily life, namely Islamic Syari'ah which encompasses everything that the human's absolute needs; there is no single condition that does not involve Sharia law at all times, places, and conditions. The meanings of Sharia include the entire event until the day of judgement. ${ }^{54}$

The nature of Syumîl and his Sa'ah of Syari'ah of Islam is not known previously in any religion, philosophy, or sect. If Risâlah is not limited to certain times and generations, then certainly not limited to places, people, nations, and certain periods. This Risâlah is aimed at all the people, all kinds, all nations, all generations, can solve all the problems of the past and the future. This is Risâlah for mankind with the law and its principle covering the whole context of human life.

Among the evidence of the Syari'ah law syumîl for every matter of life is in Qur'an in surah al-Nahl verse 9:

$$
\text { ونزلنا عليك الكتاب تبيانا لكل شيئ و هدى ورحمة وبشرى للمؤمنين }
$$

"We have sent down to you al-Quran as the clearings of all things, instruction, mercy and glad tidings of the Believers".

Referring to this, al-Imam al-Shaafa'i also expressed it beautifully and in a high-quality manner when explaining the meaning of the word of Allah swt in Sura al-Nahl verse 89 which is as follows:

$$
\text { فليست تنزل بأحد من أهل دين الله نازلة إلا وفي كتاب الله الدليلُ على سبيل الهدى فيها.5 ext }
$$

"No one of the religious experts of Allah revealed the events except in the Qur'an mentioned Dalîl as a clue to him)".

Thus, the verse and similar verse are an obvious designation of the adherence of this Islamic Syari'ah to all that the human generations at all periods and conditions.

${ }^{54}$ Aj-Jawziyyah, 28.

55 As-Syafi'î, Ar-Riqâ, cited By: Ahmad Syakir, (Egypt: Maktabah Al-Halabiy, 1940 A.D/1358 H), Juz I, 19. Al-Syafi'î, Tafsîr Al-Imâm Asy-Syâfi'iy, cited By: Ahmad ibn The Mushthafa Al-Farran, (Saudi Arabia: Dar al-Tadammuriyyah, 2006 A.D/1427 H), Juz 2, 991. 
Therefore, according to Al-Shathibiy, the Quran is named after Furqân, Hudâ, Burhân, Bayân, and tibyân likull Syay', and it is the proof of Allah against His creatures globally and detailly, Muthlaq, and 'Umûm.

Based on the explanation above, it can be concluded that the character of the Syarîah is permanent and governs the entire af âl alMukallaf in any place and time. There is nothing that should be missed. Therefore, if so, it means mustahîl for Allah SWT. When it is connected with Maqâshid asy-Syarî'ah, it can also be understood that the determination of a law in Islam must be in accordance with the will of the maker (Syâri '), Allah SWT, with patron of jalb Al-Mashâli $\underline{H}$ wa dar ' al-Mafâsid; as extent as such law determination can have a positive impact and at the same time may deny negative impacts.

\section{G. Significance of Maqâshidî Interpretation}

Consequently, the character of Syarî'ah is permanent and governs the whole af âl al-Mukallaf in every place and time, then the approach or method of Maqâshidî interpretation in interpreting Âyât al-ahkâm is an inevitor. The approach and method of interpretation that has existed in Islamic treasures do not have the responsiveness to complete dynamic of af âl al-Mukallaf.

The necessity of interpretation to the approach or method of Maqâshidî interpretation is similar to the science of Ushîl al-Figh on the science of Maqâshid asy-Syarî'ah. The discourse of Âyât al-AhhKâm interpretation discusses on the place of law formulation ${ }^{56}$ against a problem (Fi'l al-Mukallaf).

The necessity of interpretation to the approach or method of Maqâshidî interpretation is not only effective in responding to new issues that have never appeared before but also empowered to reinterpret the formulation of interpretations that have not been relevant anymore in the context of the present and the contemporary.

The determination of the meaning of Walad in the issue of inheritance of Kalâlah according to the Sunniy group is turned away from its meaning

${ }^{56}$ Al-Mundzir Mahmud ibn Muhammad ibn Mushthafa ibn ' Abd al-Lathif al-Munyawî, Sharh Mukhtashar al-Ushîl min 'Ilm al-Ushîl, (Egypt: Al-Maktabah alShâmilah, 2011 A.D./1432 H), Juz ' 1, 6. Sulaiman ibn ' Abd al-Qawi ibn al-Karim al-Thufi al-Sharshari Abu al-Rabi ' Najm al-Din (d. 716 H), Syarh Mukhtashar alRawdhah, cited by ' Abd Allah ibn ' Abd al-Muhsin al-Turkî, (TKP: Mu'assasat alRisâlah, 1987 A.D./1407 H), Juz ' 1, 254. See also: Muhammad Amin ibn Mahmud al-Bukhari, popularly known as Amir Badisyah al-Hanafiy $(972 \mathrm{H})$, Taysîr al-Tahrîr, (Beirut: Dar al-Fikr, t.th.), Juz ' 1, 10. 
of haqîqij7 (Dzakar wa untsâa [son and daughter]) to the meaning of its majâziy (Dzakar [son] only) as the consideration of the cultural aspects of Patriarchate at that time, it needs to reinterpret to keep using the meaning of haqiq $i$ to keep mal the heir due to consideration in the change of cultural aspects that occur in Indonesia. If not, Maqâshid asy-Syarî'ah in establishing the law in Indonesia can be predicted not be achieved.

The problem of mawâni 'al-irts (barriers to receiving inheritance) also needs to be developed from the existing mawâni 'al-irts formulation through the repeated interpretation of the inheritance verses. With the relatively low level of the belief of today's Moslems than the past, it is likely the occurrence of violating actions to obtain inheritance before the time; the normal death of heir. Therefore, the provisions as contained in article 173 of Presidential Decree No. 1 of 1991 on the compilation of Islamic law in Indonesia, ${ }^{66}$ is required to considered, in order to the nafs or 'Irdh of heir can be maintained.

Likewise, with other actual problems, such as the application of the principle of the authority in the inheritance, the testament for the adopted child and non-Moslem heirs, and so on, the approach and method of Maqâshidî interpretation then can be used as an alternative to solve this problem.

\section{H. Conclusion}

Based on the discussion on Maqâshid asy-Syarî'ah and the significance and urgency of Maqâshidî interpretation, it can be concluded that Maqâsshidî interpretation has a solid foundation. Therefore, Maqâshidî interpretation is expected to provide an offer to be an alternative interpretation in providing solutions for contemporary problematics and reinterpretation of the formulation of interpretations that have been out of date[.]

\section{REFERENCES}

'Abdillah, Abu Bakr Muhammad bin (w. 543 H), Ahkâm al-Qur 'ân, di-ta'lîq oleh Muhammad 'Abd al-Qadir 'Atha, Beirut: Dar al-Kutub al'Ilmiyyah, 2003 M, Juz 3.

'Asyur, Muhammad bin al-Thahir bin, Maqâshid asy-Syarî'ah al-Islâmiyyah, Tunisia: Syirkah al-Tunisiyyah, 1978 A.D, 1st Print.

${ }^{57}$ In accordance with the principles of Ushûl al-Figh:

$$
\text { الأصل في الكلام الحقيقة. }
$$

"The word is derivated from Haqîqiy". See also: ' Abd al-Rahman bin Abi Bakr Jalal al-Din al-Suyuthiy, Al-Iâh wa al-Nazhâ'ir, (Beirut: Dar al-Kutub al'ilmiyyah, 1990), Juz ' 1, 63. See also: Ahmad ibn Muhammad al-Zarqa', 106. 
Al-Amidî, Saif al-Din 'Aliy ibn Abi 'Aliy ibn Muhammad, al-Ihkâm fî Ushûl al-Ahkâm, Beirut: al-Maktab al-Islâmiy, 1402 H, Juz 3.

Al-Andalusî, Abu Muhammad 'Ali bin Ahmad bin Sa'id binHazm (w. 456 H), al-Ihkâm fî Ushîl al-Ahkâm, cited by Ahmad Muhammad Syakir, Beirut: Dar al-Afaq al-Jadidah, t.th., Juz 6.

Al-Bannanî, 'Abd al-Wahhab al-Al-'Allamah, Hâsyiyah al-Bannaniy 'alâ Syarh al-Mahalliy 'alâ Matn Jam' al-Jawâmi', Beirut: Dar al-Fikr, 1992, Volume I.

Al-Barkatî, Muhammad 'Amim al-Ihsan al-Mujaddiy, Qawâ'id al-Fiqh, alKaratisyiy, al-Shadf Bibilsyuz, 1986.

Al-Bukharî, Muhammad Amin ibn Mahmud, popular dengan sebutan Amir Badisyah al-Hanafiy $(972 \mathrm{H})$, Taysîr al-Tahrî̀, Beirut: Dar alFikr, t.th., Juz 1.

Al-Dîn, Sulaiman ibn 'Abd al-Qawi ibn al-Karim al-Thufi al-Sharshari Abu al-Rabi' Najm (w. 716 H), Syarh Mukhtashar al-Rawdhah, cited by 'Abd Allah ibn 'Abd al-Muhsin al-Turkî, (tkp: Mu’assasat al-Risâlah, 1987 A.D./1407 H), Juz 1 and 3.

Dirjen Bapera, Himpunan Peraturan Perundang-undangan Dalam Lingkungan Peradilan Agama, Jakarta: Dirjen Bapera, 2001.

Al-Dzahabî, Muhammad al-Sayyid Husain, al-Tafsîr al-Mufassirûn, Cairo: Maktabah Wahbah, 1398 H, Juz 2.

Al-Fahirî, Muhammad 'Allal bin 'Abd al-Wahid bin 'Abd al-Salam al-Fasiy, Maqâshid asy-Syarî'ah al-Islâmiyyah wa Makârimuhâ, Morroco: alRisalah, 1979 A.D, 2nd Print.

Al-Farahidî, Abi 'Abd al-Rahman al-Khalîl bin Ahmad (w. 175 H), al-'Ain, cited by Muhdî al-Makhzumî, tkp: Mu`assasah al-A'lamiy, t.th., Juz 5.

Al-Gharnathî, Ibrahim ibn Musa ibn Muhammad al-Lakhmî, al-Muwâfqât, cited by: Abû 'Ubaidah Masyhur ibn Hasan Al Salman, tkp: Dar ibn 'Affan, 1997 A.D./1417 H, Juz 3.

Al-Ghazalî, Abû Hâmid Muhammad bin Muhammad bin Muhammad (w. $505 \mathrm{H})$, al-Mustashfâ, cited by Muhammad Mushthafa Abi al-'Ala, Egypt: Maktabah al-Jundî, t.th.

Al-Hazimî, Abu 'Abdillah Ahmad bin'Umar bin Musa'id, Syarh al-Qawâa'id wa al-Ushûl al-Jâmi'ah wa al-Furûq wa al-Taqâsîm al-Badî'ah al-Nâfi'ah, http:/ / alhazme.net, Juz 8.

http:/ / muhammadidris84.blogspot.com/2009/11/tafsir-maqashidisebuah-metode. html

Ibn 'Asyur (w. 1393 H), al-Tahrîr wa al-Tanwîr (Tahrîr al-Ma'nâ al-Sadîd wa Tanwîr al-'Aql al-Jadîd min Tafsîr al-Kitâb al-Majîd), Tunisia: al-Dar alTunisiyyahlial-Nasyr, 1984 A.D, Juz 4. 
Al-Ijî̀, 'Adhd al-Dîn 'Abd al-Rahman bin Ahmad (w. 756 H), Beirut: Dar alKutub al-'Ilmiyyah, t.th., Juz 2.

Al-Isnawiî, Jamal al-Dîn 'Abd al-Rahman bin al-Hasan (w. 772 H), Nihâyat al-Sawl fì Syarh Minhâj al-Ushîl, Beirut: 'Alam al-Kutub, t.th., Juz 4.

Al-Jawharî, Isma'il bin Hammad (w. 393 H), al-Shahhâh, cited by Ahmad 'Abd al-Ghafur 'Athar, tkp: tpn, 1402 H, 2nd Print, Juz 3.

Aj-Jawziyyah, Muhammad ibn Abi Bakr ibn Ayyub ibn Sa'd Syams al-Din ibn Qayyim, I'lâm al-Muwaqqi'în 'an Rabb al-'Âlamîn, cited by: Muhammad 'Abd al-Salam Ibrahim, Beirut: Dar al-Kutub al'Ilmiyyah, 1991 A.D./1411 H, Juz 2 dan 3.

Aj-Juwainiy, Abu al-Ma'aliy 'Abd al-Muluk bin 'Abdillah (w. $478 \mathrm{H}$ ), alBurhân fî Ushûlal-Figh, cited by 'Abd al-'Azhim Dib, Cairo: Dar alAnshar, 1400 H, 2nd Print, Juz 2.

Al-Mahallî, Jalal al-Din Muhammad bin Ahmad (w. 864 H), Syarh alMahalliy 'alâ Jam' al-Jawâmi', Beirut: Dar al-Kutub al-'Ilmiyyah, t.th., Juz 2.

Mahmasani, Subhi, Falsafat al-Tasyrî̀ al-Islâmiiiy, Penerjemah: Ahmad Sujono, Filsafat Hukum dalam Islam, Bandung: al-Maarif, 1982.

Manzhur, Muhammad ibn Mukram ibn, Lisân al-'Arab, Beirut: Dar Shadir, t.th., Juz 2.

Al-Maraghî, 'Abdullah Mushthafa, al-Fath al-Mubîn fî̀ Thabaqât alUshûliyyîn, Beirut: Dar al-Kutub al-`Ilmiyyah, 1394 H, 2nd Print, Juz 2.

Al-Munyawî, Abu al-Mundzir Mahmud ibn Muhammad ibn Mushthafa ibn 'Abd al-Lathif, Syarh Mukhtashar al-Ushîl min 'Ilm al-Ushûl, Egypt: al-Maktabah al-Syâmilah, 2011 A.D/1432 H.

Al-Muqdisî, Mufiq al-Din Abi Muhammad 'Abd Allah ibn Ahmad ibn Qudamah, Rawdhat al-Nâzhir wa Jannat al-Manâzhir, Riyadh: Maktabat al-Ma'ârif, t.th., Juz 1.

Al-Qahthanî, Musfir ibn 'Aliy ibn Muhammad, Manhâj Istinbâth Ahkâm alNawâzil al-Fiqhiyyah al-Mu'âshirah; Dirâsah Ta’shîliyyah Tathbîqiyyah, Jeddah: Dar al-Andalus al-Khadhra', 2003 A.D./1424 H, Juz 1.

Al-Qarafî, Syihab al-Dîn Abî al-'Abbas Ahmad bin Idris (w. 684 H), Syarh Tanqîh al-Fushîl, cited by Thaha 'Abd al-Ra'uf Sa'ad, Egypt: alMuttahidah, 1393 H, 1st Print.

Al-Qaththân, Manna' bin Khalil, Mabâhits fì 'Ulûm al-Qur'ân, Maktabah alMu' arif li al-Nasyr wa at-Tawzi', 2000, 3rd Print.

Al-Raisunî, Ahmad, Nazhariyyât al-Maqâshid 'ind asy-Syâthibî, tkp: Mathba'ah an-Najah, 1411 H, 1st Print. 
Al-Razî, Abû 'Abdillah Muhammad bin 'Umar bin Husain (w. 606 H), alMahshîl fì 'Ilm al-Ushûl, cited by Thaha Jabir, Riyadh: Jami'ah alImâm Muhammad bin Sa'ud al-Islamiyyah, 1401 H, 1st Print, Juz 2.

Al-Subkiy, Taj al-Din 'Abd al-Wahhab bin 'Alî bin 'Abdal-Kafî (w. 771 H), Thabaqât al-Syâfi'iyyah al-Kubrâ, Beirut: Dar al-Ma'rifah, t.th., 2nd Print, Juz 4.

Al-Suyuthî, 'Abd al-Rahman bin Abi Bakr Jalal al-Din, al-Asybâh wa alNazhâ'ir, Beirut: Dar al-Kutub al-'Ilmiyyah, 1990, Juz 1.

Al-Syafi'î, Muhammad ibn Idris, al-Risâlah, cited by: Ahmad Muhammad Syakir, Beirut: al-Maktabah al-'Ilmiyyah, t.th.

-------, Tafsîr al-Imâm al-Syâfi' $\hat{\imath}$, cited by: Ahmad ibn Mushthafa alFarran, Saudi Arabia: Dar al-Tadammuriyyah, 2006 A.D/1427 H, Juz 2.

Syarifuddin, Amir, Ushul Figh, Jakarta: Logos Wacana Ilmu, 1997, 1st Print.

Taimiyah, Ibn, Majmû' al-Fatâwâ, dikumpulkan dan disusun oleh 'Abd alRahman bin Qasim al-Najdiy and son, Muhammad, Mecca: Maktabah al-Nahdhah al-Haditsah,t.th., Juz 19.

Al-Yubî, Muhammad Sa'd bin Ahmad bin Mas'ud, Maqâshid asy-Syarî́ah alIslâmiyyah wa 'Alâqatuhâ bi al-Adillat al-Syar'iyyah, Riyadh: Dar alHijrah li al-Nasyr wa al-Tawzî', 1998 A.D.

Zakariya, Abi al-Husayn Ahmad bin Faris bin (w. 395 H), Majmal al-Lughah, cited by Zuhair 'Abd al-Muhsin Sulthan, Beirut: Mu'assasah alRisalah, 1406 H, 2nd Print, Juz 2.

Al-Zarkalî, Khair al-Dîn, al-A'lâm, Beirut: Dar al-'Ilm li al-Malayin, 1992 M, 10th Print, Juz 6.

Al-Zarqâ', Ahmad bin Muhammad (w. 1357 H), Syarh al-Qawấid alFiqhiyyah, tashhîh and ta'lîq by Mushthafa Ahmad al-Zarqa', Syria: Dar al-Qalam, 1989 A.D.

Al-Zarqanî, Muhammad 'Abd al-'Azhîm, Manâhil al-'Irfân fì 'Ulûm alQur'ân, tkp: Mathba'ah 'Isa al-Babiy al-Halabiy, t.th., 3rd Print, Juz 2.

Al-Zuhailî, Wahbah, Ushûl al-Figh al-Islâmî, Syria: Dar al-Fikr, 1406 H, 1st Print, Juz 2. 
116 | AKADEMIKA, Vol. 25, No. 01 Januari-Juni 2020 